University of Nebraska - Lincoln

DigitalCommons@University of Nebraska - Lincoln

Publications from USDA-ARS / UNL Faculty

U.S. Department of Agriculture: Agricultural

Research Service, Lincoln, Nebraska

November 1993

\title{
Residual Effects of No-Till Crop Residues on Corn Yield and Nitrogen Uptake
}

\author{
M. S. Maskina \\ Punjab Agricultural University \\ James F. Power \\ University of Nebraska-Lincoln \\ John W. Doran \\ University of Nebraska-Lincoln, jdoran1@unl.edu \\ Wallace Wilhelm \\ University of Nebraska-Lincoln, wwilhelm1@unl.edu
}

Follow this and additional works at: https://digitalcommons.unl.edu/usdaarsfacpub

Part of the Agricultural Science Commons

\footnotetext{
Maskina, M. S.; Power, James F.; Doran, John W.; and Wilhelm, Wallace, "Residual Effects of No-Till Crop Residues on Corn Yield and Nitrogen Uptake" (1993). Publications from USDA-ARS / UNL Faculty. 90. https://digitalcommons.unl.edu/usdaarsfacpub/90
}

This Article is brought to you for free and open access by the U.S. Department of Agriculture: Agricultural Research Service, Lincoln, Nebraska at DigitalCommons@University of Nebraska - Lincoln. It has been accepted for inclusion in Publications from USDA-ARS / UNL Faculty by an authorized administrator of DigitalCommons@University of Nebraska - Lincoln. 


\title{
Residual Effects of No-Till Crop Residues on Corn Yield and Nitrogen Uptake
}

\author{
M. S. Maskina, J. F. Power, ${ }^{*}$ J. W. Doran, and W. W. Wilhelm
}

\begin{abstract}
The residual effects of crop residues on $\mathbf{N}$ availability and crop growth are largely unknown. A field experiment was conducted from 1986 through 1988 at Lincoln, NE, to determine the residual effects on no-till corn (Zea mays $L$.) production and $N$ uptake of $0,50,100$, and $150 \%$ of the amount of crop residues produced by the previous crop during the previous $5 \mathrm{yr}$. These effects were evaluated with and without tillage (disking), $\mathrm{N}$ fertilizer (60 $\mathrm{kg} \mathrm{N} \mathrm{ha}^{-1}$ ), and hairy vetch (Vicia villosa Roth ssp. villosa, 'Madison') winter cover crop. Increasing the previous crop residue rate increased organic $\mathrm{C}$, total $\mathrm{N}$, and $\mathrm{NO}_{3}-\mathrm{N}$ in the upper $30 \mathrm{~cm}$ of soil as much as 10,12 , and $66 \%$, respectively. Growth and $\mathbf{N}$ uptake by corn (3-yr average) generally increased as previous residue rate increased. Corn grain and stover production was 17 and $25 \%$ greater for the highest compared with the lowest previous residue rate. Uptake of indigenous soil $\mathrm{N}$, but not fertilizer $\mathbf{N}$, also increased as previous residue rate increased. Cover crops generally increased growth and $\mathbf{N}$ uptake with no fertilizer, but had little effect with $\mathbf{N}$ fertilizer. Soil properties, crop growth, and $\mathbf{N}$ uptake generally were not affected by tillage or interactions among the variables. These results indicate that increasing no-till crop residue rates increased the capability of this soil to provide $\mathrm{N}$ to growing crops for many years. It appears this effect is somewhat self-perpetuating.
\end{abstract}

$\mathrm{C}^{\mathrm{k}}$ ROP FERTILIZER REQUIREMENT and soil nutrient availability are influenced by soil fertility and crop residue management. Crop residues contain appreciable plant nutrients and, therefore, have contributed to the maintenance of soil productivity if returned to the soil (Holland and Coleman, 1987; Paul and Juma, -1981). Returning residues also helps maintain soil organic matter, which is important for soil structure, soil and water conservation, and soil microbial and faunal activity. Furthermore, the microenvironment in residue-covered soils is usually less oxidative than where residues are removed or incorporated (Doran, 1980). Prolonged removal or burning of crop residues usually decreases nutrient and organic matter content (Hooker and Schepers, 1984; Unger, 1973).

The effects of clean tillage and soil erosion on decreased soil organic matter content and loss of productivity have been documented frequently (Prasad and Power, 1991; Unger and McCalla, 1980). These adverse effects are largely overcome by use of reduced or no tillage and by use of cover crops (Doran et al., 1984; Smith et al., 1987; Unger and McCalla, 1980). Stratification of crop residues and conservation of soil organic matter near the soil surface with reduced or no-till management are paralleled by greater soil microbial biomass in these layers, which causes greater immobilization of fertilizer $\mathrm{N}$, compared with plowing

M.S. Maskina, Punjab Agricultural Univ., Ludhiana, Punjab, India; J.F. Power, J.W. Doran, and W.W. Wilhelm, USDA-ARS, Univ. of Nebraska, Lincoln, NE 68583. Published as Paper no. 10438, Journal Series, Nebraska Agricultural Research Division, Lincoln. Received 27 Apr. 1992. *Corresponding author.

Published in Soil Sci. Soc. Am. J. 57:1555-1560 (1993). or shallow tillage (Carter and Rennie, 1987; Doran and Smith, 1987). In Kansas, Hooker and Schepers (1984) showed greater soil $\mathrm{N}$ and $\mathrm{C}$ and plant $\mathrm{N}$ availability after more than $10 \mathrm{yr}$ of adding crop residues vs. burning. In Montana, Black (1973) showed that addition of wheat (Triticum aestivium L.) straw also increased soil $\mathrm{N}$ and $\mathrm{C}$ and mineralizable $\mathrm{N}$. Use of legume cover crops likewise adds organic matter to soils and affects soil $\mathrm{N}$ transformations (Janzen et al., 1990; Varco et al., 1989).

A number of studies have been published in which the effects of tillage, cover crops, $\mathbf{N}$ fertilization, and soil organic matter individually influenced $\mathrm{N}$ availability and uptake by a crop. Some studies have also investigated the effects of combinations of several of these factors, but few have simultaneously investigated the interactions between more than two of these factors that affect $\mathbf{N}$ availability and uptake. In nature, however, there are numerous environmental and cultural factors operating and interacting simultaneously that affect soil $\mathrm{N}$ availability. Consequently, we studied the simultaneous effects and interactions of tillage, cover crop, $\mathbf{N}$ fertilization, and soil organic matter level on $\mathrm{N}$ availability and uptake by dryland corn. Differences in soil organic matter content were established in an earlier 5-yr experiment (1981-1985) in which crop residues were added to no-till plots at rates of $0,50,100$, and $150 \%$ of the quantity of residues produced by the previous crop (Power et al., 1986; Wilhelm et al., 1986).

\section{MATERIALS AND METHODS}

This study was conducted from 1986 through 1988 on a Crete-Butler silty clay loam (fine, montmorillonitic, mesic Pachic Argiustoll-Abruptic Argiaquoll) near Lincoln, NE. Climatic is continental with typically $70 \%$ of the average $717 \mathrm{~mm}$ of annual precipitation falling between April and September. However, rainfall distribution is highly variable. The experimental site is nearly level $(0.2 \%$ slope $)$.

In an earlier 5-yr experiment, we returned either 0, 50, 100, or $150 \%$ of the crops residues produced by the previous crop (either corn or soybean [Glycine max (L.) Merr.]) to the soil surface in a no-till production system (Power et al., 1986; Wilhelm et al., 1986). In the 3-yr experiment reported here, which utilized the same plots as the previous 5-yr residue rate experiment, we discontinued the variable crop residue rates (that is, all residues produced by the previous crop were left on each plot), and we measured the residual effects of the previous no-till residue rates on crop growth and soil properties. In addition, we determined the effects of tillage (no-till and tilled), winter legume cover crop (hairy vetch), and fertilizer $\mathrm{N}\left(0\right.$ and $\left.60 \mathrm{~kg} \mathrm{~N} \mathrm{ha}^{-1}\right)$ on dryland corn production for each of the previous residue rates. The experimental units were arranged as split plots within a randomized complete block design. Main treatments were tillage, with previous residue rates as subblocks. The $\mathrm{N}$ fertilizer and cover crop treatments were randomized within each previous residue rate plot, in 9.1 by $9.1 \mathrm{~m}$ subplots replicated four times.

At the initiation and several times during the experiment, soil samples were collected in the spring for laboratory char- 
Table 1. Monthly precipitation and mean temperature during 1986, 1987, and 1988 growing seasons at Lincoln, NE.

\begin{tabular}{|c|c|c|c|c|c|c|c|c|}
\hline \multirow[b]{2}{*}{ Month } & \multicolumn{4}{|c|}{ Precipitation } & \multicolumn{4}{|c|}{ Temperature } \\
\hline & 1986 & 1987 & 1988 & $\begin{array}{c}\text { Nor- } \\
\text { mal }\end{array}$ & 1986 & 1987 & 1988 & $\begin{array}{c}\text { Nor- } \\
\text { mal }\end{array}$ \\
\hline & - & $-m$ & & - & 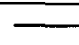 & - & $C$ & \\
\hline April & 159 & 62 & 62 & 69 & 12.7 & 12.8 & 10.5 & 11.3 \\
\hline May & 75 & 86 & 95 & 96 & 18.6 & 19.9 & 20.3 & 17.5 \\
\hline June & 113 & 69 & 18 & 108 & 25.2 & 25.2 & 26.7 & 23.1 \\
\hline July & 141 & 47 & 51 & 91 & 26.7 & 27.4 & 26.6 & 25.8 \\
\hline August & 159 & 193 & 61 & 87 & 22.3 & 23.6 & 26.7 & 24.7 \\
\hline September & 147 & 30 & 140 & 82 & 20.9 & 20.8 & 20.1 & 19.9 \\
\hline October & 154 & 75 & 1 & 51 & 12.7 & 10.3 & 10.5 & 13.2 \\
\hline
\end{tabular}

Table 2. Soil characteristics at two dates as influenced by the level of crop residues returned to the soil in the $5 \mathrm{yr}$ previous to this study.

\begin{tabular}{|c|c|c|c|c|c|}
\hline Soil properties & $0 \%$ & $50 \%$ & $100 \%$ & $150 \%$ & $\begin{array}{c}\text { LSD } \\
(0.10)\end{array}$ \\
\hline \multicolumn{6}{|c|}{ 0-30 cm, collected April 1986} \\
\hline $\begin{array}{l}\text { Organic matter, } \mathrm{g} \mathrm{kg}^{-1} \\
\text { Total } \mathrm{N}, \mathrm{g} \mathrm{kg}^{-1} \\
\mathrm{NO}_{3}-\mathrm{N}, \mathrm{mg} \mathrm{kg}^{-1} \\
\mathrm{NH}_{4}-\mathrm{N}, \mathrm{mg} \mathrm{kg}^{-1}\end{array}$ & $\begin{array}{r}24.7 \\
1.23 \\
4.52 \\
12.52\end{array}$ & $\begin{array}{r}25.3 \\
1.14 \\
6.86 \\
17.42\end{array}$ & $\begin{array}{r}26.2 \\
1.30 \\
5.28 \\
14.35\end{array}$ & $\begin{array}{r}27.4 \\
1.37 \\
7.51 \\
11.75\end{array}$ & $\begin{array}{l}2.2 \\
0.12 \\
1.40 \\
3.17\end{array}$ \\
\hline \multicolumn{6}{|c|}{ 0-7.5 cm, collected October 1987} \\
\hline $\begin{array}{l}\text { Soil bulk density, } \mathrm{Mg} \mathrm{m}^{-3} \\
\text { Microbial biomass, } \mathrm{kg} \mathrm{ha}^{-1} \\
\text { Total soil organic } \mathrm{C}, \mathrm{g} \mathrm{kg}^{-1} \\
\text { Total } \mathrm{N}, \mathrm{g} \mathrm{kg}^{-1} \\
\text { Water-holding capacity, } \mathrm{g} \mathrm{kg}^{-1}\end{array}$ & $\begin{array}{c}1.36 \\
142 \\
16.5 \\
1.38 \\
540\end{array}$ & $\begin{array}{c}1.31 \\
246 \\
16.6 \\
1.41 \\
570\end{array}$ & $\begin{array}{c}1.28 \\
164 \\
17.3 \\
1.47 \\
580\end{array}$ & $\begin{array}{c}1.27 \\
165 \\
18.9 \\
1.56 \\
560\end{array}$ & $\begin{array}{l}\text { NS } \\
\text { NS } \\
1.8 \\
0.10 \\
30\end{array}$ \\
\hline
\end{tabular}

acterization of organic matter content, total $\mathrm{N}$, microbial biomass, and mineralized $N$, using methods outlined in Page et al. (1982). Bulk density and total water-holding capacity were also determined (Klute et al., 1986).

Corn (cv. Nebraska 611) was planted in $0.76-\mathrm{m}$ row spacing at 42000,37500 and 39700 kernels ha ${ }^{-1}$ on 14 May 1986, 9 June 1987, and 12 May 1988, respectively. Appropriate corn plots were overseeded (broadcast) with $30 \mathrm{~kg}$ hairy vetch seed ha $^{-1}$ near 1 September each fall. In April 1987, hairy vetch growth was very poor due to excessive March and early April rainfall. Hence soybean, a substitute legume cover crop, was planted on 27 April and killed and incorporated on 8 June. For $\mathrm{N}$-fertilized subplots, $\mathrm{NH}_{4} \mathrm{NO}_{3}$ was broadcast at $60 \mathrm{~kg} \mathrm{~N}^{-1}$ within 1 wk of corn planting. In 1987, ${ }^{15} \mathrm{~N}$-depleted $\mathrm{NH}_{4} \mathrm{NO}_{3}$ was substituted on one-half of each subplot. This process was repeated in 1988 on the other half of $\mathrm{N}$-fertilized subplots. Legume cover crops were killed with 2,4-D amine (amine salt of 2,4-dichlorophenoxyacetic acid) and dicamba (2-methoxy3-6-dichlorobenzoic acid) in no-till plots and were incorporated by disking in tilled plots 1 to $2 \mathrm{~d}$ before corn planting. Biomass and $\mathrm{N}$ accumulation in the aboveground portion of legume cover crops were determined by harvesting four $0.5-\mathrm{m}^{2}$ quadrat per plot before killing the legume. At maturity, grain and stover yields were determined by hand harvesting $5.0 \mathrm{~m}^{2} \mathrm{plot}^{-1}$. Plant samples were analyzed for total $\mathrm{N}$ by modified micro-Kjeldahl digestion followed by $\mathrm{NH}_{4}^{+}$determination using automated colorometric procedures (Schuman et al., 1973). The isotopic ratio of ${ }^{15} \mathrm{~N}$ and ${ }^{14} \mathrm{~N}$ in plant and soil samples was determined by mass spectrometry (Schepers et al., 1989). Nitrogen content derived from fertilizer (NDFF) was calculated, and from these data uptake of soil and fertilizer $\mathrm{N}$ was determined. An analysis of variance was made on all data collected, and means were
Table 3. Effect of previous crop residue levels on growth and $\mathrm{N}$ accumulation in cover crops.

\begin{tabular}{|c|c|c|c|c|c|}
\hline Year & $0 \%$ & $50 \%$ & $100 \%$ & $150 \%$ & LSD (0.10) \\
\hline \multicolumn{6}{|c|}{$\longrightarrow \mathrm{kg} \mathrm{ha}^{-1} \longrightarrow$} \\
\hline \multicolumn{6}{|c|}{ Total dry biomass of winter legume } \\
\hline $\begin{array}{l}1986 \\
1987 \dagger \\
1988 \\
\text { Avg. }\end{array}$ & $\begin{array}{r}640 \\
660 \\
1200 \\
830\end{array}$ & $\begin{array}{r}810 \\
680 \\
1640 \\
1040\end{array}$ & $\begin{array}{r}850 \\
520 \\
1450 \\
940\end{array}$ & $\begin{array}{r}1250 \\
590 \\
1750 \\
1200\end{array}$ & $\begin{array}{c}390 \\
\text { NS } \\
360 \\
350\end{array}$ \\
\hline \multicolumn{6}{|c|}{$\mathrm{N}$ accumulation in aboveground portion } \\
\hline $\begin{array}{l}1986 \\
1987 \\
1988 \\
\text { Avg. }\end{array}$ & $\begin{array}{l}26.8 \\
31.7 \\
32.7 \\
26.2\end{array}$ & $\begin{array}{l}30.5 \\
20.7 \\
46.4 \\
32.5\end{array}$ & $\begin{array}{l}32.6 \\
16.2 \\
41.5 \\
30.1\end{array}$ & $\begin{array}{l}47.2 \\
18.5 \\
42.2 \\
36.0\end{array}$ & $\begin{array}{c}14.2 \\
\text { NS } \\
8.8 \\
9.3\end{array}$ \\
\hline
\end{tabular}

$\uparrow$ Soybean grown as cover crop.

separated by calculating least significant differences at $P=$ 0.10 .

\section{RESULTS}

Growing conditions for corn during the $3 \mathrm{yr}$ of this study varied widely (Table 1 ). Precipitation distribution and air temperature regimes in 1986 were favorable for dryland corn production and grain yields were high. In 1987 , brief periods of drought and high temperatures occurred between tasselling and maturity, resulting in a more typical year for dryland corn production in this region. Precipitation in June, July, and August 1988 was below the long-term average, which, when coupled with abnormally high air temperatures, severely stressed the crop during pollination and grain fill.

Before starting the experiment in April 1986, surface soil samples were analyzed to evaluate the effect on soil properties of crop residues applied in the previous study (Table 2). Average quantity of crop residues added annually the previous $5 \mathrm{yr}$ varied from 0 to about $6 \mathrm{Mg}$ $\mathrm{ha}^{-1}(150 \%$ rate). Addition of $150 \%$ crop residues increased soil organic matter by $10 \%$, total $\mathrm{N}$ by $12 \%$, and $\mathrm{NO}_{3}-\mathrm{N}$ by $66 \%$ over respective values for complete residue removal $(0 \%)$. Likewise, at later soil sampling dates (Table 2), increased rates of previous crop residues tended to positively influence several soil properties associated with enhanced crop yields, such as microbial biomass, water-holding capacity, and total water-filled pore space (Doran and Smith, 1987; Prasad and Power, 1991). Effects of previous crop residue rate on soil bulk density were generally not significant. Interaction between previous crop residue treatments and the cover crop, fertilizer $\mathbf{N}$ rate, or tillage treatment imposed during this study were seldom statistically significant for the parameters investigated.

Average total biomass of hairy vetch was significantly higher for the $150 \%$ than for $0 \%$ previous residue rates during 1986 and 1988 (Table 3). In 1987, however, growth of soybean (substituted as a cover crop) was not affected by previous crop residue treatment. Compared with the $0 \%$ previous residue treatment, total dry matter production by hairy vetch averaged $33 \%$ greater for the $50 \%$ treatment, $25 \%$ greater for the $100 \%$ treatment, and $63 \%$ greater for the $150 \%$ treatment. Likewise total $\mathrm{N}$ accu- 
Table 4. Grain and stover dry weights (3-yr average), as affected by previous residue rate and $\mathrm{N}$ fertilization.

\begin{tabular}{|c|c|c|c|c|c|c|}
\hline \multirow{2}{*}{$\begin{array}{l}\text { Previous } \\
\text { residue } \\
\text { rate }\end{array}$} & \multicolumn{3}{|c|}{ Grain } & \multicolumn{3}{|c|}{ Stover } \\
\hline & $0 \mathrm{~kg} \mathrm{~N} \mathrm{ha} a^{-1}$ & $60 \mathrm{~kg} \mathrm{~N} \mathrm{ha-1}^{-1}$ & Avg. & $0 \mathrm{~kg} \mathrm{~N} \mathrm{ha}^{-1}$ & $60 \mathrm{~kg} \mathrm{~N} \mathrm{ha}^{-1}$ & Avg. \\
\hline \multicolumn{7}{|l|}{$\overline{\%}$} \\
\hline 0 & 3950 & 5290 & 4620 & 2580 & 3510 & 3050 \\
\hline 50 & 4220 & 5510 & 4870 & 3110 & 4000 & 3560 \\
\hline 100 & 4370 & 5290 & 4830 & 3140 & 3550 & 3350 \\
\hline 150 & 4900 & 5830 & 5360 & 3480 & 4140 & 3810 \\
\hline Avg. & 4360 & 5480 & 4920 & 3080 & 3800 & 3440 \\
\hline LSD $(0.10)$ & & & 380 & & & 480 \\
\hline
\end{tabular}

mulation in hairy vetch dry matter was 29,25 , and $50 \%$ greater for these three respective previous residue levels. The only significant interaction for both hairy vetch dry weight and $\mathrm{N}$ uptake resulted from greater response to increased previous $5 \mathrm{yr}$ residue rate for no-till than for tilled plots (data not shown). Concentration of $\mathrm{N}$ in cover crops was not influenced by previous crop residue treatment.

Previous crop residue rate significantly increased the 3-yr average yield of corn grain and stover over all $\mathrm{N}$ fertilizer, tillage, and cover crop treatments (Table 4). Grain and stover yields were 16 and $25 \%$ greater for the highest ( $150 \%$ level) than the lowest $(0 \%$ level) previous crop residue treatments. Grain yields were significantly affected by previous crop residue rate, $\mathrm{N}$ fertilization, and year, but not by tillage or winter cover crop. Mean grain yields in 1986 were $6500 \mathrm{~kg} \mathrm{ha}^{-1}, 4950 \mathrm{~kg} \mathrm{ha}^{-1}$ in 1987 , and $3300 \mathrm{~kg} \mathrm{ha}^{-1}$ in 1988 . Responses to $\mathrm{N}$ were greatest in $1986\left(1690 \mathrm{~kg} \mathrm{ha}^{-1}\right)$ and least in $1988(1000$ $\left.\mathrm{kg} \mathrm{ha}^{-1}\right)$. There was a significant cover crop $\times \mathrm{N}$ interaction for grain yields (Fig. 1). With no fertilizer $\mathrm{N}$, there was a positive response to winter cover crop, whereas the response was negative with $60 \mathrm{~kg} \mathrm{~N} \mathrm{ha}^{-1}$, and the response to $\mathrm{N}$ was considerably greater without than with the winter cover crop.

Regression coefficients ( $r$ values) relating mean corn grain yields to certain soil properties were 0.921 for organic C, 0.976 for total $N$, and -0.794 for bulk density. These results indicate that grain yield was associated positively with soil organic $\mathrm{C}$ and total soil $\mathrm{N}$ and negatively with bulk density.

Corn stover yield (3-yr average) was significantly affected by tillage, previous residue rate, $\mathrm{N}$ fertilization, tillage $\times \mathrm{N}$ interaction, and year. Effects of winter cover crop were not significant, nor were other interactions. Average stover yields were increased by no-till, $\mathrm{N}$ fertilization, and increasing previous residue rate (Table 4). Dry weights for no-till were $3590 \mathrm{~kg} \mathrm{ha}^{-1}$, compared with $3290 \mathrm{~kg} \mathrm{ha}^{-1}$ for tilled plots. Average stover yields for 1986 were $2960 \mathrm{~kg} \mathrm{ha}^{-1}, 3100 \mathrm{~kg} \mathrm{ha}^{-1}$ for 1987 , and $5130 \mathrm{~kg} \mathrm{ha}^{-1}$ for 1988 , a trend essentially opposite to that for corn grain yields. Consequently, total biomass produced by the corn varied much less between years than did either grain or stover production. Total biomass production averaged $9560 \mathrm{~kg} \mathrm{ha}^{-1}$ for $1986,8050 \mathrm{~kg}$ $\mathrm{ha}^{-1}$ for 1987 , and $8480 \mathrm{~kg} \mathrm{ha}^{-1}$ for 1988 .

The significant tillage $\times \mathrm{N}$ interaction for stover production resulted from the fact that average stover yields showed no effect of tillage without $N\left(3030 \mathrm{~kg} \mathrm{ha}^{-1}\right.$ for tilled and $3130 \mathrm{~kg} \mathrm{ha}^{-1}$ for no-till), whereas with $60 \mathrm{~kg}$ $\mathrm{N}$ ha-1 ${ }^{-1}$ stover production was $490 \mathrm{~kg} \mathrm{ha}^{-1}$ greater from no-till than from tilled plots (4050 and $3560 \mathrm{~kg} \mathrm{ha}^{-1}$, respectively). Response to $\mathrm{N}$ fertilizer was, therefore, $920 \mathrm{~kg} \mathrm{ha}^{-1}$ for no-till, compared with only $530 \mathrm{~kg} \mathrm{ha}^{-1}$ for tilled plots.

Neither previous crop residue rate, tillage practice, $\mathrm{N}$ fertilization, winter cover crop, nor interactions between any of these variables affected grain to stover ratio (Table 4). However, the year strongly affected this ratio, with average values of 2.01 for $1986,1.58$ for 1987 , and 0.68 for 1988 . This, coupled with only slight variation in total biomass among years, suggested that growing conditions during pollination and grain fill greatly affected the translocation of photosynthate from stover into grain. This process appeared to be most efficient in the most favorable season (1986), but was greatly restricted by the water and heat stress experienced during late summer in 1988.

Total $\mathrm{N}$ concentration in corn grain increased with previous crop residue rate, $\mathrm{N}$ fertilization, and the use of a winter cover crop (Table 5). Also, yearly average corn grain $\mathbf{N}$ concentrations were inversely related to grain yield, with largest values in 1988, the most stressful year. The cover crop $\times \mathrm{N}$ fertilizer interaction was also significant because $\mathbf{N}$ fertilization increased corn grain $\mathrm{N}$ concentration by $3.2 \mathrm{~g} \mathrm{~kg}^{-1}$ without a winter cover crop, compared with only a $2.4 \mathrm{~g} \mathrm{~kg}^{-1}$ increase with a cover crop (Table 5). Total $\mathrm{N}$ concentration of

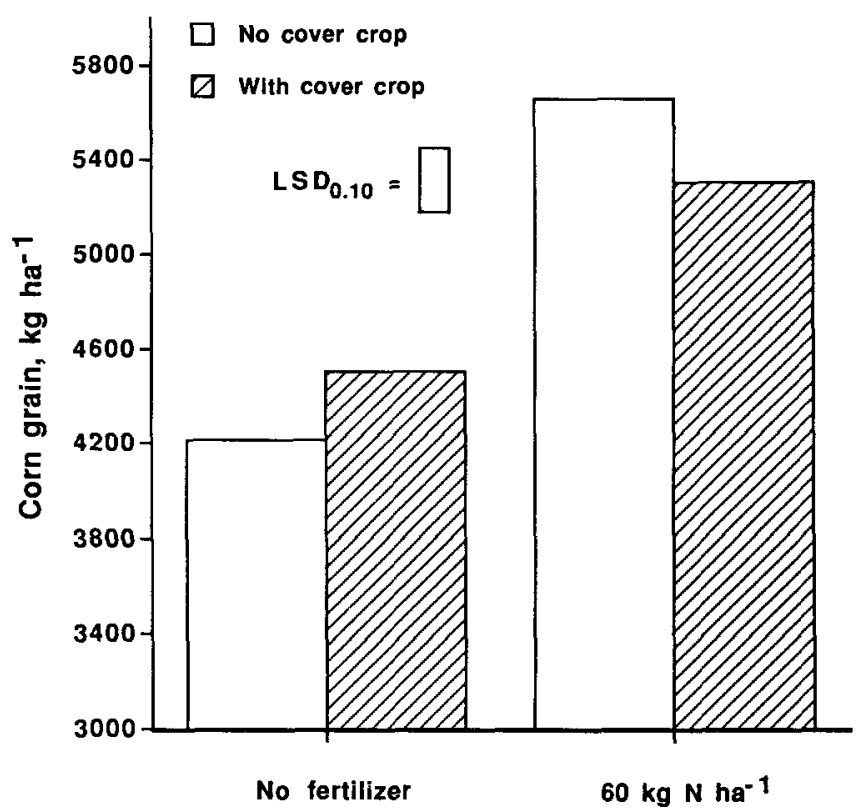

Fig. 1. Cover crop and $N$ fertilizer effects on corn grain yield (3-yr average). 
Table 5. Average ( 3 yr) total $\mathbf{N}$ concentrations in corn grain and stover as affected by previous crop residue rate, $\mathbf{N}$ fertilization, and winter cover crop.

\begin{tabular}{|c|c|c|c|c|c|c|c|c|c|c|c|}
\hline \multirow{3}{*}{$\begin{array}{l}\text { Winter } \\
\text { cover }\end{array}$} & \multirow{3}{*}{$\underset{\text { rate }}{\mathbf{N}}$} & \multicolumn{10}{|c|}{ Total $\mathbf{N}$ concentration } \\
\hline & & \multicolumn{2}{|c|}{$0 \%$} & \multicolumn{2}{|c|}{$50 \%$} & \multicolumn{2}{|c|}{$100 \%$} & \multicolumn{2}{|c|}{$150 \%$} & \multicolumn{2}{|c|}{ Avg. } \\
\hline & & Grain & Stover & Grain & Stover & Grain & Stover & Grain & Stover & Grain & Stover \\
\hline & $\mathrm{kg} \mathrm{ha}^{-1}$ & & & & & $-\mathrm{g}$ & $3^{-1}$ & & & & \\
\hline With & $\begin{array}{c}0 \\
60 \\
\text { Avg. } \dagger\end{array}$ & $\begin{array}{l}12.6 \\
15.1 \\
13.8\end{array}$ & $\begin{array}{l}4.8 \\
5.9 \\
5.4\end{array}$ & $\begin{array}{l}12.6 \\
15.0 \\
13.8\end{array}$ & $\begin{array}{l}4.3 \\
5.9 \\
5.1\end{array}$ & $\begin{array}{r}13.2 \\
15.6 \\
4.4\end{array}$ & $\begin{array}{l}4.5 \\
6.2 \\
5.4\end{array}$ & $\begin{array}{l}13.4 \\
15.4 \\
14.4\end{array}$ & $\begin{array}{l}4.7 \\
6.1 \\
5.4\end{array}$ & $\begin{array}{l}12.9 \\
15.3 \\
14.1\end{array}$ & $\begin{array}{l}4.6 \\
6.0 \\
5.3\end{array}$ \\
\hline Without & $\begin{array}{c}0 \\
60 \\
\text { Avg. } \dagger\end{array}$ & $\begin{array}{l}11.3 \\
14.6 \\
13.0\end{array}$ & $\begin{array}{l}4.1 \\
5.0 \\
4.6\end{array}$ & $\begin{array}{l}11.3 \\
14.3 \\
12.8\end{array}$ & $\begin{array}{l}4.2 \\
5.1 \\
4.7\end{array}$ & $\begin{array}{l}11.5 \\
15.2 \\
13.4\end{array}$ & $\begin{array}{l}4.2 \\
5.7 \\
5.0\end{array}$ & $\begin{array}{l}11.8 \\
14.5 \\
13.2\end{array}$ & $\begin{array}{l}4.3 \\
5.6 \\
5.0\end{array}$ & $\begin{array}{l}11.5 \\
14.7 \\
13.1\end{array}$ & $\begin{array}{l}4.2 \\
5.4 \\
4.8\end{array}$ \\
\hline Average & $\begin{array}{r}0 \ddagger \\
60 \ddagger \\
\text { Avg.\$ }\end{array}$ & $\begin{array}{l}11.9 \\
14.9 \\
13.4\end{array}$ & $\begin{array}{l}4.4 \\
5.5 \\
5.0\end{array}$ & $\begin{array}{l}11.9 \\
14.6 \\
13.3\end{array}$ & $\begin{array}{l}4.2 \\
5.5 \\
4.9\end{array}$ & $\begin{array}{l}12.3 \\
15.4 \\
13.9\end{array}$ & $\begin{array}{l}4.4 \\
6.0 \\
5.2\end{array}$ & $\begin{array}{l}12.6 \\
15.0 \\
13.8\end{array}$ & $\begin{array}{l}4.5 \\
5.8 \\
5.2\end{array}$ & $\begin{array}{l}12.2 \\
15.0 \\
13.6\end{array}$ & $\begin{array}{l}4.4 \\
5.7 \\
5.1\end{array}$ \\
\hline
\end{tabular}

† LSD (0.10) for winter cover crop averages $=0.8$ and 0.1 for grain and stover, respectively.

$\neq$ LSD (0.10) for $\mathrm{N}$ fertilizer averages $=0.4$ and 0.2 for grain and stover, respectively.

$\S \mathrm{LSD}(0.10)$ for previous residue rate averages $=0.6$ and NS for grain and stover, respectively.

corn stover was also significantly increased by $\mathrm{N}$ fertilization and by winter cover crop, and it was largest in 1988 , the most stressful year. The effects of tillage were not significant for either grain or stover $\mathrm{N}$ concentrations.

The 3-yr average $\mathrm{N}$ uptake by corn grain (Table 6) increased as previous crop residue rate increased, with $\mathbf{N}$ fertilization, and with use of winter cover crops. Tillage effects were not significant. Grain $\mathrm{N}$ uptake was greatest in the most favorable year (1986) and least in the most stressful year (1988). The only interaction with significant effects was $\mathbf{N} \times$ winter cover crop because winter cover crop increased grain $\mathrm{N}$ uptake when no $\mathrm{N}$ was applied, but decreased it slightly with fertilizer $\mathrm{N}$.

Stover $\mathbf{N}$ uptake followed the patterns shown for grain $\mathrm{N}$ uptake (Table 6) in that stover $\mathbf{N}$ uptake increased with increased previous crop residue rate, $\mathrm{N}$ fertilization, and winter cover crop. Tillage had no effect but, unlike grain $\mathrm{N}$ uptake, stover $\mathrm{N}$ uptake was much greater in the most stressful year (1988) than in previous years. This again suggests that the climatic stresses experienced in
1988 inhibited the translocation of $\mathrm{N}$ from vegetative to reproductive tissue during the grain fill period. No interactions significantly affected stover $\mathrm{N}$ uptake.

Total $\mathrm{N}$ uptake (3-yr average) also followed patterns established for grain $\mathrm{N}$ uptake in that previous crop residue level, $\mathbf{N}$ fertilizer, winter cover crop, year, and $\mathbf{N}$ $\times$ cover crop all had significant effects, but tillage and all other interactions were not significant (Table 6). Total $\mathrm{N}$ uptake for 1986 and 1988 were similar, again indicating that the hot, dry weather experienced during pollination and grain fill in 1988 adversely affected N translocation.

The NDFF in corn grain and stover was determined in 1987 and 1988, with values for grain averaging $2.9 \%$ greater in 1988 than in 1987 . Neither year nor any variable studied affected NDFF in stover (Table 7). In grain, NDFF values were greater without than with the cover crop (Table 7). Previous crop residue rate also significantly affected NDFF for grain, but variations failed to follow a linear pattern with rate. Neither tillage nor any of the interactions had significant effects on NDFF.

Table 6. Three-year average corn grain, stover, and total $\mathrm{N}$ uptake as affected by previous crop residue rate, $\mathrm{N}$ fertilization, and winter cover crop.

\begin{tabular}{|c|c|c|c|c|c|c|c|c|c|c|c|}
\hline & \multicolumn{11}{|c|}{ N uptake } \\
\hline & \multicolumn{2}{|c|}{$0 \%$} & \multicolumn{2}{|c|}{$50 \%$} & \multicolumn{2}{|c|}{$100 \%$} & \multicolumn{2}{|c|}{$150 \%$} & \multicolumn{2}{|c|}{ Average $\dagger$} & \multirow[b]{2}{*}{ Avg. $\neq$} \\
\hline & $0 \mathrm{~kg} \mathrm{~N}$ & $60 \mathrm{~kg} \mathrm{~N}$ & $0 \mathrm{~kg} \mathrm{~N}$ & $60 \mathrm{~kg} \mathrm{~N}$ & $0 \mathrm{~kg} \mathrm{~N}$ & $60 \mathrm{~kg} \mathrm{~N}$ & $0 \mathrm{~kg} \mathrm{~N}$ & $60 \mathrm{~kg} \mathrm{~N}$ & $0 \mathrm{~kg} \mathrm{~N}$ & $60 \mathrm{~kg} \mathrm{~N}$ & \\
\hline & & & & & & out cover & & & & & \\
\hline \multirow{4}{*}{$\begin{array}{l}\text { Grain } \\
\text { Stover } \\
\text { Total }\end{array}$} & 43.4 & 78.6 & 45.5 & 77.7 & 49.8 & 82.8 & 57.9 & 86.2 & 49.1 & 81.3 & 65.2 \\
\hline & 9.5 & 16.3 & 11.3 & 17.5 & 11.4 & 17.7 & 12.3 & 19.7 & 11.1 & 17.8 & 14.5 \\
\hline & 52.9 & 94.9 & 56.8 & 95.2 & 61.2 & 100.5 & 70.2 & 105.9 & 60.2 & 99.1 & 79.7 \\
\hline & \multicolumn{11}{|c|}{ With cover crop } \\
\hline Grain & 51.4 & 73.8 & 56.2 & 79.2 & 59.0 & 74.4 & 65.6 & 84.7 & 58.0 & 78.0 & 68.0 \\
\hline Stover & 10.9 & 23.3 & 11.6 & 25.7 & 12.9 & 24.6 & 16.0 & 29.2 & 12.9 & 25.7 & 19.3 \\
\hline \multirow[t]{2}{*}{ Total } & 62.3 & 97.1 & 67.8 & 104.9 & 71.9 & 99.0 & 81.6 & 113.9 & 70.9 & 103.7 & 87.3 \\
\hline & \multicolumn{11}{|c|}{ Average } \\
\hline Grain§ & 47.4 & 76.2 & 50.8 & 78.5 & 54.4 & 78.6 & 61.8 & 85.4 & 53.6 & 79.7 & 66.6 \\
\hline Stover§ & 10.2 & 19.8 & 11.5 & 21.6 & 12.1 & 21.2 & 14.2 & 24.5 & 12.0 & 21.7 & 16.9 \\
\hline Total§ & 57.6 & 96.0 & 62.3 & 100.1 & 66.5 & 99.8 & 76.0 & 109.9 & 65.6 & 101.4 & 83.5 \\
\hline
\end{tabular}

$\dagger$ LSD (0.10) for $\mathrm{N}$ fertilizer averages $=3.4,6.2$, and $9.1 \mathrm{~kg} \mathrm{ha}^{-1}$ for grain, stover, and total, respectively.

$\ddagger$ LSD (0.10) for winter cover crop averages $=2.7,3.7$, and $5.2 \mathrm{~kg} \mathrm{ha}^{-1}$ for grain, stover, and total, respectively.

$\S \operatorname{LSD}(0.10)$ for previous residue rate averages $=7.6,4.7$, and $9.1 \mathrm{~kg} \mathrm{ha}^{-1}$ for grain, stover, and total, respectively. 
Table 7. Nitrogen (2-yr average) in grain and stover derived from fertilizer as affected by previous crop residue and winter cover crop.

\begin{tabular}{|c|c|c|c|c|c|}
\hline & \multicolumn{5}{|c|}{$\mathrm{N}$ derived from fertilizer } \\
\hline & $0 \%$ & $50 \%$ & $100 \%$ & $150 \%$ & Avg. $\dagger$ \\
\hline & & & ut cover & & \\
\hline \multirow[t]{2}{*}{$\begin{array}{l}\text { Grain } \\
\text { Stover }\end{array}$} & $\begin{array}{l}28.1 \\
26.9\end{array}$ & $\begin{array}{l}33.9 \\
27.7\end{array}$ & $\begin{array}{l}28.4 \\
27.2\end{array}$ & $\begin{array}{l}28.5 \\
27.0\end{array}$ & $\begin{array}{l}29.7 \\
27.2\end{array}$ \\
\hline & \multicolumn{5}{|c|}{ With cover crop } \\
\hline \multirow[t]{2}{*}{$\begin{array}{l}\text { Grain } \\
\text { Stover }\end{array}$} & $\begin{array}{l}26.5 \\
26.3\end{array}$ & $\begin{array}{l}27.6 \\
27.7\end{array}$ & $\begin{array}{l}23.7 \\
24.6\end{array}$ & $\begin{array}{l}22.1 \\
22.3\end{array}$ & $\begin{array}{l}25.0 \\
25.2\end{array}$ \\
\hline & \multicolumn{5}{|c|}{ Average +} \\
\hline $\begin{array}{l}\text { Grain } \\
\text { Stover }\end{array}$ & $\begin{array}{l}27.3 \\
26.6\end{array}$ & $\begin{array}{l}30.7 \\
27.7\end{array}$ & $\begin{array}{l}26.1 \\
25.8\end{array}$ & $\begin{array}{l}25.3 \\
24.6\end{array}$ & $\begin{array}{l}27.3 \\
26.2\end{array}$ \\
\hline
\end{tabular}

Uptake of $\mathrm{N}$ from the ${ }^{15} \mathrm{~N}$-depleted fertilizer was significantly affected by previous crop residue rate (in a nonlinear manner) and was decreased by the use of a winter cover crop (Table 8). Effects of tillage and most interactions were not significant. Likewise, tillage had no significant effect on uptake of $\mathrm{N}$ from mineralized soil $\mathrm{N}$. However, soil $\mathrm{N}$ uptake did increase with increased previous crop residue rate, $\mathrm{N}$ fertilization, and the use of a winter cover crop. Any $\mathrm{N}$ mineralized from decomposition of the legume cover crop would be included in this calculation of soil $\mathrm{N}$ uptake. There was also a significant fertilizer $\mathrm{N} \times$ cover crop interaction because of a large response to the cover crop when no $\mathrm{N}$ fertilizer was applied, compared with essentially no response with $\mathrm{N}$ fertilizer. Like fertilizer $\mathrm{N}$ uptake, the magnitude of the $\mathrm{N} \times$ cover crop interaction for soil $\mathrm{N}$ uptake varied significantly with previous crop residue rate.

\section{DISCUSSION AND CONCLUSIONS}

Under conditions of this experiment, the type of tillage used generally had little influence on corn growth and $\mathrm{N}$ uptake, but effects of previous crop residue rates were significant throughout. The response to previous crop residue rate may have partially resulted from increased mineralization and uptake of $\mathrm{N}$ from the enlarged soil organic $\mathrm{N}$ pool, as suggested by the data in Table 8 .

Corn stover production increased about $700 \mathrm{~kg} \mathrm{ha}^{-1}$ as previous crop residue rate increased from 0 to $150 \%$ levels (Table 4). Thus, according to the earlier research on these plots (Wilhelm et al., 1986; Power et al., 1986), this increased crop residue cover should have conserved more soil water and enhanced growth of the following crop. Soil water data (not shown) confirmed that more water was present in the higher residue soils. Therefore, the effects of previous crop residue rate on increased corn growth and $\mathrm{N}$ uptake observed in this experiment probably resulted from alterations of the soil environment that affected both soil water conditions and soil $\mathrm{N}$ availability.

Linn and Doran (1984) showed that aerobic processes (such as mineralization and nitrification) were greatest when about $60 \%$ of the soil pore volume was filled with
Table 8. Average (2-yr) soil and fertilizer $N$ uptake by corn (whole plant) as affected by previous crop residue rate, $\mathbf{N}$ fertilization, and winter cover crop.

\begin{tabular}{|c|c|c|c|c|c|c|}
\hline $\begin{array}{l}\text { Cover } \\
\text { сrop }\end{array}$ & $\begin{array}{c}\mathrm{N} \\
\text { rate }\end{array}$ & $0 \%$ & $50 \%$ & $100 \%$ & $150 \%$ & Avg. $\dagger$ \\
\hline & \multicolumn{6}{|c|}{$-\mathbf{k g ~ N} \mathbf{h a}^{-1}$} \\
\hline & \multicolumn{6}{|c|}{$\underline{\text { Soil N uptake }}$} \\
\hline Without & $\begin{array}{r}0 \\
60\end{array}$ & $\begin{array}{l}50.9 \\
73.2\end{array}$ & $\begin{array}{l}58.7 \\
67.2\end{array}$ & $\begin{array}{l}65.7 \\
73.6\end{array}$ & $\begin{array}{l}75.9 \\
74.4\end{array}$ & $\begin{array}{l}62.8 \\
72.1\end{array}$ \\
\hline With & $\begin{array}{r}0 \\
60\end{array}$ & $\begin{array}{l}60.2 \\
68.6\end{array}$ & $\begin{array}{l}63.6 \\
73.2\end{array}$ & $\begin{array}{l}\mathbf{7 2 . 3} \\
\mathbf{7 0 . 7}\end{array}$ & $\begin{array}{l}83.7 \\
83.2\end{array}$ & $\begin{array}{l}70.0 \\
73.9\end{array}$ \\
\hline \multirow[t]{2}{*}{ Average } & $\begin{array}{r}0 \ddagger \\
60 \ddagger \\
\text { Avg.\$ }\end{array}$ & $\begin{array}{l}55.6 \\
70.9 \\
63.2\end{array}$ & $\begin{array}{l}61.2 \\
70.2 \\
65.7\end{array}$ & $\begin{array}{l}69.0 \\
72.2 \\
70.5\end{array}$ & $\begin{array}{l}79.8 \\
78.8 \\
79.3\end{array}$ & $\begin{array}{l}66.4 \\
73.0 \\
69.7\end{array}$ \\
\hline & \multicolumn{6}{|c|}{ Fertilizer $N$ uptake } \\
\hline Without & 60 & 28.6 & 34.5 & 29.2 & 29.6 & 30.5 \\
\hline With & 60 & 24.8 & 27.7 & 21.9 & 23.6 & 24.5 \\
\hline Average & $60 \S$ & 26.7 & 31.1 & 25.6 & 26.6 & 27.5 \\
\hline
\end{tabular}

$\uparrow$ LSD (0.10) for cover crop averages $=4.1$ and 3.7 for soil and fertilizer $\mathrm{N}$ uptake, respectively.

$¥ \operatorname{LSD}(0.10)$ for $\mathrm{N}$ fertilizer averages $=4.6$ (soil $\mathrm{N}$ uptake).

$\S$ LSD (0.10) for previous residue rate averages $=6.4$ and 4.0 for soil and fertilizer uptake, respectively.

water. According to results from Doran et al. (1984), returning more crop residues to the $150 \%$ treatment plots in this experiment should have maintained soil water content closer to the ideal of $60 \%$ water-filled pore space than would have occurred for the $0 \%$ previous residue plots. This was verified by the soil water measurements made in this experiment (data not shown). Thus, one would expect greater mineralization in the $150 \%$ than the $0 \%$ treated soils.

The interactive effects of the legume cover crop and $\mathrm{N}$ fertilization observed in this experiment on corn growth and $\mathrm{N}$ uptake were generally predictable. Beneficial effects of the legume cover crop were usually observed without $\mathrm{N}$ fertilization, but these effects were reduced or eliminated with $\mathrm{N}$ fertilization. These effects were often greatest at the lowest previous crop residue rate, presumably because of greater $\mathrm{N}$ stress for this treatment than the $150 \%$ treatment.

From these results it appears that the effects of crop residue rate may have a prolonged residual effect on crop growth and $\mathrm{N}$ availability. That these residual effects themselves enhance crop growth, and subsequently the quantity of residues returned, indicates that a somewhat self-perpetuating situation is created that can continue to influence productivity for many years. This appears to be an added benefit from maintaining crop residues that has not previously been specifically identified.

\section{ACKNOWLEDGMENTS}

This research was supported in part by funding from the USAID US/INDO Science and Technology Information Program, supporting M.S. Maskina for 16 mo while working on this project.

\section{REFERENCES}

Black, A.L. 1973. Soil property changes associated with crop residue management in a wheat-fallow rotation. Soil Sci. Soc. Am. J. 37:943-946. 
Carter, M.R., and D.A. Rennie. 1987. Effects of tillage on deposition and utilization of ${ }^{15} \mathrm{~N}$ residual fertilizer. Soil Tillage Res. 9:33-43.

Doran, J.W. 1980. Microbial changes associated with residue management with reduced tillage. Soil Sci. Soc. Am. J. 44:518 523.

Doran, J.W., and M.S. Smith. 1987. Organic matter management and utilization of soil and fertilizer nutrients. p. 53-72. In R.F. Follett et al. (ed.) Soil fertility and organic matter as critical components of production systems. SSSA Spec. Publ. 19. ASA and SSSA, Madison, WI

Doran, J.W., W.W. Wilhelm, and J.F. Power. 1984. Crop residue removal and soil productivity with no-till corn, sorghum, and soybean. Soil Sci. Soc. Am. J. 48:640-645.

Holland, E.A., and D.C. Coleman. 1987. Litter placement effects on microbial and organic matter dynamics in an agroecosystem. Ecology 68:423-433.

Hooker, M.L., and J.S. Schepers. 1984. Effect of residue removal vs. incorporation on $\mathrm{N}$ uptake and growth of winter wheat. $\mathrm{p}$. 207. In Agronomy abstracts. ASA, Madison, WI.

Janzen, H.H., J.B. Bole, V.O. Biederbeck, and A.E. Slinkard. 1990. Fate of $\mathrm{N}$ applied as green manure or ammonium fertilizer to soil subsequently cropped with spring wheat at three sites in western Canada. Can. J. Soil Sci. 70:313-323.

Klute, A., G.S. Campbell, R.D. Jackson, M.M. Mortland, and D.R. Nielsen. 1986. Methods of soil analysis. Part I. 2nd ed. Agron. Monogr. 9. ASA and SSSA, Madison, WI.

Linn, D.M., and J.W. Doran. 1984. Effect of water-filled pore space on carbon dioxide and nitrous oxide production in tilled and nontilled soils. Soil Sci. Soc. Am. J. 48:1267-1272.
Page, A.L., R.H. Miller, and K.R. Kenney (ed.) 1982. Methods of soil analysis. Part 2. 2nd ed. Agron. Monogr. 9. ASA and SSSA, Madison, WI.

Paul, E.A., and N.G. Juma. 1981. Mineralization and immobilization of soil nitrogen by microorganisms. Ecol. Bull. (Stockholm) 33:179-195.

Power, J.F., J.W. Doran, and W.W. Wilhelm. 1986. Crop residue effects on soil environment and dryland maize and soybean production. Soil Tillage Res. 8:101-111.

Prasad, R., and J.F. Power. 1991. Crop residue management Literature review. Adv. Soil Sci. 15:205-251.

Schepers, J.S., D.D. Francis, and M.T. Thompson. 1989. Simultaneous determination of total $\mathrm{C}$, total $\mathrm{N}$, and ${ }^{15} \mathrm{~N}$ on soil and plant material. Commun. Soil Sci. Plant Anal. 20:949-959.

Schuman, G.E., M.A. Stanley, and D. Knudsen. 1973. Automated total nitrogen analysis of soil and plant samples. Soil Sci. Soc. Am. Proc. 37:480-481.

Smith, M.S., W.W. Frye, and J.J. Varco. 1987. Legume winter cover crops. Adv. Soil Sci. 7:95-139.

Unger, P.W. 1973. Straw mulch rate effect on soil water storage and sorghum yield. Soil Sci. Soc. Am. Proc. 42:486-491.

Unger, P.W., and T.M. McCalla. 1980. Conservation tillage systems. Adv. Agron. 33:1-58.

Varco, J.J., W.W. Frye, M.S. Smith, and C.T. McKown. 1989. Tillage effects on nitrogen recovery from a nitrogen-15 labeled legume cover crop. Soil Sci. Soc. Am. J. 53:822-827.

Wilhelm, W.W., J.W. Doran, and J.F. Power. 1986. Corn and soybean yield response to crop residue management under notillage production systems. Agron. J. 78:184-189. 